\title{
Synthesis of cyclic nitrone and 1,2-oxazine from 1,2,4-triaryl-but-2-ene-1,4-dione and hydroxylamine
}

\author{
MUTHUPANDI NAGARAJ ${ }^{\mathrm{a}}$, MURUGAN INIYA ${ }^{\mathrm{a}}$, MUTHUSAMY BOOMINATHAN $^{\mathrm{a}}$, \\ SHANMUGAM MUTHUSUBRAMANIAN ${ }^{\mathrm{a}, *}$ and NATTAMAI BHUVANESH ${ }^{\mathrm{b}}$ \\ ${ }^{a}$ Department of Organic Chemistry, School of Chemistry, Madurai Kamaraj University, \\ Madurai 625 021, India \\ ${ }^{\mathrm{b}}$ X-ray Diffraction Laboratory, Department of Chemistry, Texas A \& M University, \\ College Station, TX 77842, USA \\ e-mail: muthumanian2001@yahoo.com
}

MS received 1 November 2011; revised 20 January 2012; accepted 29 February 2012

\begin{abstract}
The reaction of hydroxylamine hydrochloride with differently substituted phenyldibenzoylethylene has been investigated. Both cyclic nitrone and 1,2-oxazine have been isolated and characterized by one- and two-dimensional NMR data and also by single crystal X-ray analysis.
\end{abstract}

Keywords. 1,2,-Oxazines; cyclic nitrones; 1,4-diketones; regioselectivity; two-dimensional NMR.

\section{Introduction}

Cyclic nitrones have drawn special attention due to their successful application as building blocks in the synthesis of various natural and biologically active compounds. ${ }^{1}$ They are commonly used as precursors ${ }^{2}$ in the synthesis of a variety of heterocycles, as spintrapping reagents in the identification of transient radicals $^{3}$ and as therapeutic agents. ${ }^{4}$ Nitrones possess one of the largest dipole moments known for any functional group type (3.37-3.47 D) making them potentially useful for NLO applications and control of molecular orientation. They offer a simple route to stable radicals via one-electron electrochemical reduction. ${ }^{5}$ Annealation of imidazolidinyl-based nitronyl nitroxides leads to stable planar spin delocalized radicals, the benzonitronyl nitroxides, which exhibit strong magnetic exchange through efficient $\pi-\pi$ stacking interactions in the solid state. ${ }^{6}$

1,2-Oxazines have gained interest in organic synthesis as useful intermediates ${ }^{7}$ in the synthesis of natural products ${ }^{8}$ and unnatural cyclic amino acids. ${ }^{9}$ 1,2-Oxazines exhibit a broad spectrum of biological activities. $^{10}$

We are interested in the reactions of different nucleophiles with diketones in the process of generating new heterocycles. ${ }^{11}$ In this connection, it has been planned to investigate the reaction of phenyldibenzoylethylene

*For correspondence with hydroxylamine hydrochloride. A few references ${ }^{12}$ are available in which the reaction of unsubstituted phenyldibenzoylethylene with hydroxylamine hydrochloride has been mentioned, but a systematic study has now been carried out in order to (i) analyse the structure of the products unambiguously, (ii) look upon the regioselectivity, if any, in the case of substituted phenyldibenzoylethylene and (iii) ascertain the mechanism of the reaction.

\section{Experimental}

\subsection{General}

Nuclear Magnetic Resonance $\left({ }^{1} \mathrm{H}\right.$ and ${ }^{13} \mathrm{C}$ NMR $)$ spectra were recorded on a Bruker $300 \mathrm{MHz}$ spectrometer in $\mathrm{CDCl}_{3}$ using TMS as an internal standard. Chemical shifts are reported in parts per million $(\delta)$, coupling constants ( $J$ values) are reported in Hertz $(\mathrm{Hz}) .{ }^{13} \mathrm{C}$ NMR spectra were routinely run with broadband decoupling. Infrared spectra were recorded on a Shimatzu FT-IR instrument (in $\mathrm{KBr}$ pellet). Band positions are reported in reciprocal centimeters $\left(\mathrm{cm}^{-1}\right)$. Melting points were determined on a melting point apparatus (Inlab Pvt Ltd, India) equipped with a thermometer and were uncorrected. Column chromatography was carried out in silica gel (60-120 mesh) using petroleum ether-ethyl acetate as eluent. Elemental analyses were performed on a Perkin Elmer 2400 series II Elemental CHNS analyzer. 

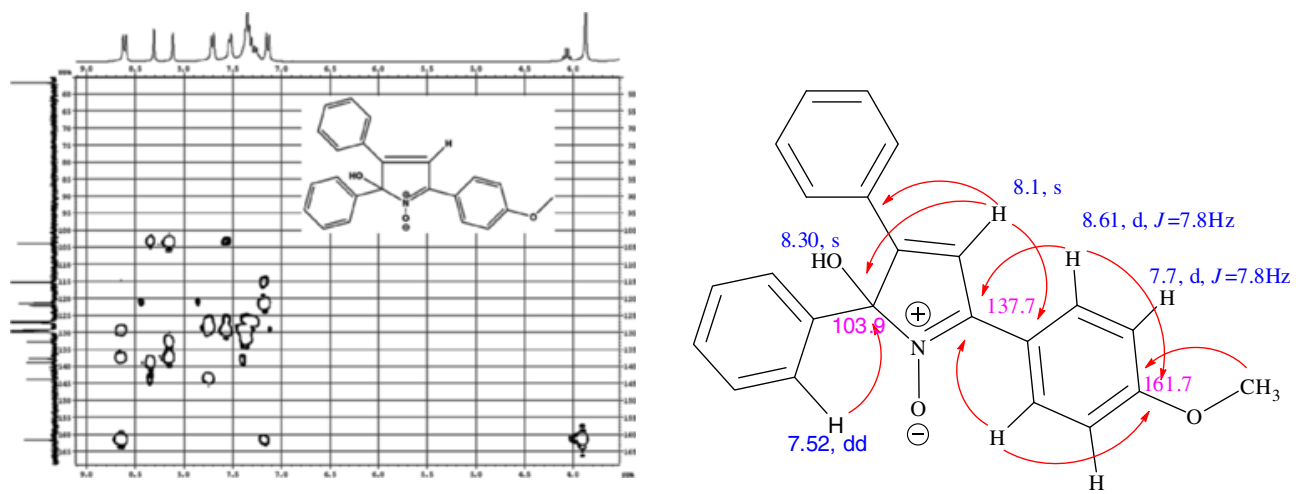

Figure 1. HMBC-NMR spectra of 7e and some selected correlation diagram.

\subsection{General procedure}

A mixture of 1,2-diphenyl-4-arylbut-2-ene-1,4-dione (2) (3.61 mmol), hydroxylamine hydrochloride $(7.22 \mathrm{mmol})$ and sodium acetate $(7.22 \mathrm{mmol})$ in ethanol was heated under reflux for $2 \mathrm{~h}$. After completion of the reaction, the reaction mixture was poured into crushed ice and filtered. The crude product was purified by column chromatography using petroleum ether-ethyl acetate mixture as eluent to yield $\mathbf{7}$ and $\mathbf{4 / 8}$.

2.2a 4-(5-Bromothiophen-2-yl)-4-(hydroxyimino)-1,2diphenylbut-2-en-1-one $(\mathbf{4 f})$ : Yellow colour solid; m.p. $156-158^{\circ} \mathrm{C}$; IR (KBr) 3625, 1654, 1632, $1210 \mathrm{~cm}^{-1}$; ${ }^{1} \mathrm{H}$ NMR $\left(300 \mathrm{MHz}, \mathrm{CDCl}_{3}\right): \delta=7.10(\mathrm{~d}, J=4.2 \mathrm{~Hz}$, $1 \mathrm{H}), 7.25-7.29(\mathrm{~m}, 3 \mathrm{H}), 7.39-7.43(\mathrm{~m}, 3 \mathrm{H}), 7.46$ (s, 1H), $7.57(\mathrm{~d}, J=4.2 \mathrm{~Hz}, 1 \mathrm{H}), 7.58-7.66(\mathrm{~m}, 4 \mathrm{H})$, $8.44(\mathrm{~s}, 1 \mathrm{H}) ;{ }^{13} \mathrm{C}$ NMR $\left(75 \mathrm{MHz}, \mathrm{CDCl}_{3}\right): \delta=120.5$, 123.0, 126.4, 127.2, 128.5, 129.2, 129.6, 130.6, 131.3, 131.9, 133.7, 135.2, 147.2, 149.0, 156.9, 179.3; Anal. Calcd. for $\mathrm{C}_{20} \mathrm{H}_{14} \mathrm{BrNO}_{2} \mathrm{~S}$ (\%): C, 58.26; H, 3.42; N, $3.40 ; \mathrm{S}, 7.78$. Found (\%): C, 58.02; H, 3.26; N, 3.24; S, 7.62 .

2.2b 2-Hydroxy-2,4,5-triphenyl-2H-pyrrole-1-oxide (7a): Yellow colour solid; m.p. $179-181^{\circ} \mathrm{C}$ (lit. m.p. $\left.179^{\circ} \mathrm{C}\right){ }^{12 \mathrm{a}} \mathrm{IR}(\mathrm{KBr}) 3088,3061,2850,1674,1593$, $1523,1485,1371,1205 \mathrm{~cm}^{-1} ;{ }^{1} \mathrm{H}$ NMR $(300 \mathrm{MHz}$, $\left.\mathrm{CDCl}_{3}\right): \delta=6.75(\mathrm{~s}, 1 \mathrm{H}), 7.24-7.63(\mathrm{~m}, 13 \mathrm{H}), 8.09(\mathrm{dd}$, $J=7.8 \mathrm{~Hz}, 1.2 \mathrm{~Hz}, 2 \mathrm{H}) ;{ }^{13} \mathrm{C} \mathrm{NMR}\left(75 \mathrm{MHz}, \mathrm{CDCl}_{3}\right)$ : $\delta=103.9,117.6,125.7,126.5,127.2$, * 127.9, 128.3, 128.5, 128.6, 128.9, 129.2, 130.9, 136.7, 140.5, 146.9; Anal. Calcd. for $\mathrm{C}_{22} \mathrm{H}_{17} \mathrm{NO}_{2}$ (\%): C, 80.71; H, 5.23; $\mathrm{N}, 4.28$. Found (\%): C, 80.59; H, 5.12; N, 4.09. * two carbons are merged together.

2.2c 5-(4-Chlorophenyl)-2-hydroxy-2,4-diphenyl-2Hpyrrole-1-oxide $(\mathbf{7 b})$ : Yellow colour solid; m.p. 152- $154^{\circ} \mathrm{C}$; IR (KBr): 3095, 2939, 2840, 1665, 1598, 1531, 1438, 1213, $780 \mathrm{~cm}^{-1}$; ${ }^{1} \mathrm{H}$ NMR $\left(300 \mathrm{MHz}, \mathrm{CDCl}_{3}\right)$ : $\delta=6.81(\mathrm{~s}, 1 \mathrm{H}), 7.25-7.55(\mathrm{~m}, 13 \mathrm{H}) 8.12(\mathrm{~d}, J=$ $7.2 \mathrm{~Hz}, 2 \mathrm{H}) ;{ }^{13} \mathrm{C}$ NMR $\left(75 \mathrm{MHz}, \mathrm{CDCl}_{3}\right): \delta=103.1$, 117.2, 126.0, 126.5, 127.2, 127.9 128.0, 128.3, 128.7, 128.9, 129.0, 129.6, 131.2, 136.9, 140.4, 144.5; Anal. Calcd. for $\mathrm{C}_{22} \mathrm{H}_{16} \mathrm{ClNO}_{2}(\%): \mathrm{C}, 73.03 ; \mathrm{H}, 4.46 ; \mathrm{N}$, 3.87. Found (\%): C, 72.92; H, 4.35; N, 3.76 .

2.2d 5-(4-Bromophenyl)-2-hydroxy-2,3-diphenyl-2Hpyrrole-1-oxide (7c): Yellow colour solid; m.p. 171$173^{\circ} \mathrm{C}$; IR (KBr) 3075, 3028, 2846, 1671, 1591, 1524, 1438, 1213, $688 \mathrm{~cm}^{-1}$; ${ }^{1} \mathrm{H}$ NMR $(300 \mathrm{MHz}$, DMSO$\left.d_{6}\right): \delta=7.11-7.24(\mathrm{~m}, 6 \mathrm{H}), 7.38-7.41(\mathrm{~m}, 2 \mathrm{H})$, $7.54(\mathrm{~d}, J=7.5 \mathrm{~Hz}, 2 \mathrm{H}), 7.64(\mathrm{~d}, J=8.7 \mathrm{~Hz}, 2 \mathrm{H})$, $8.02(\mathrm{~s}, 1 \mathrm{H}), 8.32(\mathrm{~s}, 1 \mathrm{H}), 8.42(\mathrm{~d}, J=8.7 \mathrm{~Hz}, 2 \mathrm{H})$; ${ }^{13} \mathrm{C}$ NMR $\left(75 \mathrm{MHz}\right.$, DMSO- $\left.d_{6}\right): \delta=104.7,121.0$, $124.3,126.8,127.2,128.4,129.4,129.6,129.7,129.8$, 130.0, 132.6, 132.9, 137.4, 138.5, 143.8; Anal. Calcd. for $\mathrm{C}_{22} \mathrm{H}_{16} \mathrm{BrNO}_{2}(\%)$ : C, 65.04; $\mathrm{H}, 3.97 ; \mathrm{N}, 3.45$. Found (\%): C, 64.92; H, 3.84; N, 3.29.

2.2e 2-Hydroxy-2,3-diphenyl-5-p-tolyl-2H-pyrrole-1oxide (7d): Yellow colour solid; m.p. $151-153^{\circ} \mathrm{C}$; IR (KBr) 3067, 2938, 2825, 1662, 1596, 1529, $1438 \mathrm{~cm}^{-1} ;{ }^{1} \mathrm{H}$ NMR (300 MHz, DMSO- $\left.d_{6}\right): \delta=2.39$ (s, 3H), 7.24-7.53 (m, 10H), $7.66(\mathrm{~d}, J=7.2 \mathrm{~Hz}$, 2H), $7.90(\mathrm{~s}, 1 \mathrm{H}), 8.30(\mathrm{~s}, 1 \mathrm{H}), 8.44(\mathrm{~d}, J=7.2 \mathrm{~Hz}$, $2 \mathrm{H}) ;{ }^{13} \mathrm{C}$ NMR $\left(75 \mathrm{MHz}, \mathrm{DMSO}-d_{6}\right): \delta=19.5,101.4$, $118.0,123.6,123.8,124.3,125.1,126.3,126.4,126.6$, 126.8, 127.4, 129.7, 135.4, 135.7, 138.3, 141.3; Anal. Calcd. for $\mathrm{C}_{23} \mathrm{H}_{19} \mathrm{NO}_{2}(\%)$ : C, 80.92; $\mathrm{H}, 5.61 ; \mathrm{N}, 4.10$. Found (\%): C, 80.79; H, 5.54; N, 3.96.

$2.2 \mathrm{f}$ 2-Hydroxy-5-(4-methoxyphenyl)-2,3-diphenyl2H-pyrrole-1-oxide (7e): Yellow colour solid; m.p. 163-165 ${ }^{\circ}$; IR (KBr): 3088, 3022, 2927, 2816, 1657 , 
1589, 1531, $1438 \mathrm{~cm}^{-1}$; ${ }^{1} \mathrm{H}$ NMR $(300 \mathrm{MHz}$, DMSO$\left.d_{6}\right): \delta=3.48(\mathrm{~s}, 3 \mathrm{H}), 7.13(\mathrm{~d}, J=8.7 \mathrm{~Hz}, 2 \mathrm{H})$, 7.23-7.37 (m, 6H), 7.51-7.53 (m, 2H), $7.70(\mathrm{~d}, J=$ $7.5 \mathrm{~Hz}, 2 \mathrm{H}), 8.11(\mathrm{~s}, 1 \mathrm{H}), 8.30(\mathrm{~s}, 1 \mathrm{H}), 8.61(\mathrm{~d}, J=$ $8.7 \mathrm{~Hz}, 2 \mathrm{H}) ;{ }^{13} \mathrm{C}$ NMR $\left(75 \mathrm{MHz}, \mathrm{DMSO}-d_{6}\right): \delta=56.6$, $103.9,115.3,121.5,122.1,126.9,127.1,129.2,129.5$, 129.7, 129.8, 130.9, 132.7, 137.7, 138.9, 143.9, 161.7; Anal. Calcd. for $\mathrm{C}_{23} \mathrm{H}_{19} \mathrm{NO}_{3}(\%)$ : C, 77.29; H, 5.36; N, 3.92. Found (\%): C, 77.18; H, 5.28; N, 3.80.

2.2g 5-(5-Bromothiophen-2-yl)-2-hydroxy-2,3-diphenyl2H-pyrrole 1-oxide (7f): Yellow colour solid; m.p. 144-146 ${ }^{\circ} \mathrm{C}$; IR (KBr): 3068, 2929, 2847, 1669, $1592 \mathrm{~cm}^{-1} ;{ }^{1} \mathrm{H}$ NMR $\left(300 \mathrm{MHz}, \mathrm{CDCl}_{3}\right): \delta=6.77$ (s, $1 \mathrm{H}), 7.05(\mathrm{~d}, J=4.2 \mathrm{~Hz}, 1 \mathrm{H}), 7.10(\mathrm{~d}, J=4.2 \mathrm{~Hz}$, 1H). 7.25-7.35 (m, 6H), 7.59-7.62 (m, 5H); ${ }^{13} \mathrm{C} \mathrm{NMR}$ $\left(75 \mathrm{MHz}, \mathrm{CDCl}_{3}\right): \delta=102.7,114.8,119.2,125.8$, $126.9,128.6,128.7,129.4$, ${ }^{*} 129.5, * 130.2,130.6$, 136.2, 137.9, 148.6; Anal. Calcd. for $\mathrm{C}_{20} \mathrm{H}_{14} \mathrm{BrNO}_{2} \mathrm{~S}$ (\%): C, 58.26; H, 3.42; N, 3.40; S, 7.78. Found (\%): C, 58.08; H, 3.34; N, 3.31; S, 7.65. * two carbons are merged together.

2.2h 3,5,6-Triphenyl-6H-1,2-oxazin-6-ol (8a): Yellow colour solid; m.p. $159-160^{\circ} \mathrm{C}$; IR (KBr): 3198, 1624, 1491, 1209, 1008, $692 \mathrm{~cm}^{-1}$; ${ }^{1} \mathrm{H}$ NMR $(300 \mathrm{MHz}$, $\left.\mathrm{CDCl}_{3}\right): \delta=3.99(\mathrm{bs}, 1 \mathrm{H}), 6.75(\mathrm{~s}, 1 \mathrm{H}), 7.15-7.55$ $(\mathrm{m}, 13 \mathrm{H}), 7.80(\mathrm{dd}, J=7.8 \mathrm{~Hz}, 1.2 \mathrm{~Hz}, 2 \mathrm{H}) ;{ }^{13} \mathrm{C}$ NMR (75 MHz, $\left.\mathrm{CDCl}_{3}\right): \delta=97.4,113.0,126.2,127.3$, 127.8, ${ }^{*} 128.1,128.2,128.6,128.8,129.9,133.8,135.6$, 139.7, 143.2, 153.3; Anal. Calcd. for $\mathrm{C}_{22} \mathrm{H}_{17} \mathrm{NO}_{2}(\%)$ : C, 80.71; H, 5.23; N, 4.28. Found (\%): C, 80.58; H, $5.17 ; \mathrm{N}, 4.23$. * two carbons are merged together.

2.2i 3-(4-Chlorophenyl)-5,6-diphenyl-6H-1,2-oxazin6-ol $(8 \boldsymbol{b})$ : Yellow colour solid; m.p. $163-165^{\circ} \mathrm{C}$; IR (KBr): 3192, 1632, 1497, 1212, 1012, $725 \mathrm{~cm}^{-1} ;{ }^{1} \mathrm{H}$
NMR (300 MHz, DMSO- $\left.d_{6}\right): \delta=4.01$ (bs, $\left.1 \mathrm{H}\right), 6.75$ $(\mathrm{s}, 1 \mathrm{H}), 7.15-7.55(\mathrm{~m}, 12 \mathrm{H}), 7.80(\mathrm{~d}, J=7.2 \mathrm{~Hz}$, $2 \mathrm{H}) ;{ }^{13} \mathrm{C}$ NMR $\left(75 \mathrm{MHz}, \mathrm{DMSO}-d_{6}\right): \delta=97.6,112.9$, $126.4,127.5,127.8,127.9,128.2,128.5,128.7,128.9$, 130.0, 133.2, 135.4, 139.5, 143.5, 152.1; Anal. Calcd. for $\mathrm{C}_{22} \mathrm{H}_{16} \mathrm{ClNO}_{2}(\%)$ : C, 73.03; $\mathrm{H}, 4.46 ; \mathrm{N}, 3.87$. Found (\%): C, 72.92; H, 4.35; N, 3.75.

$2.2 \mathrm{j}$ 3-(4-Bromophenyl)-5,6-diphenyl-6H-1,2-oxazin6-ol (8c): Yellow colour solid; m.p. $172-174^{\circ} \mathrm{C}$; IR (KBr): 3201, 1629, 1496, 1205, 1002, $682 \mathrm{~cm}^{-1}$; ${ }^{1} \mathrm{H}$ NMR $\left(300 \mathrm{MHz}, \mathrm{DMSO}-d_{6}\right): \delta=6.95(\mathrm{~s}, 1 \mathrm{H})$, 7.11-7.16 (m, 6H), 7.34-7.41 (m, 4H), $7.61(\mathrm{~d}, J=$ $8.1 \mathrm{~Hz}, 2 \mathrm{H}), 7.79(\mathrm{~d}, J=8.1 \mathrm{~Hz}, 2 \mathrm{H}), 8.06(\mathrm{~s}, 1 \mathrm{H}) ;{ }^{13} \mathrm{C}$ NMR $\left(75 \mathrm{MHz}, \mathrm{DMSO}-d_{6}\right): \delta=96.2,111.6,122.7$, $126.8,127.0,127.4,127.8,127.9,128.4,131.2$, 131.7, 132.6, 135.1, 140.5, 141.2, 151.1; Anal. Calcd. for $\mathrm{C}_{22} \mathrm{H}_{16} \mathrm{BrNO}_{2}$ (\%): C, 65.04; H, 3.97; N, 3.45. Found (\%): C, 64.91; H, 4.02; N, 3.34 .

2.2k 5,6-Diphenyl-3-p-tolyl-6H-1,2-oxazin-6-ol (8d): Yellow colour solid; m.p. $146-148^{\circ} \mathrm{C}$; IR (KBr): 3192 , 1641, 1497, 1222, 1011, $656 \mathrm{~cm}^{-1}$; ${ }^{1} \mathrm{H}$ NMR $(300 \mathrm{MHz}$, $\left.\mathrm{CDCl}_{3}\right): \delta=2.39(\mathrm{~s}, 3 \mathrm{H}), 4.10(\mathrm{~s}, 1 \mathrm{H}), 6.71(\mathrm{~s}, 1 \mathrm{H})$, $7.19-7.51(\mathrm{~m}, 12 \mathrm{H}), 7.68(\mathrm{~d}, J=7.5 \mathrm{~Hz}, 2 \mathrm{H}) ;{ }^{13} \mathrm{C}$ NMR $\left(75 \mathrm{MHz}, \mathrm{CDCl}_{3}\right): \delta=21.3,97.2,113.0,126.0$, 127.3, 127.7, 128.0, 128.1, 128.5, 128.7, 129.4, 130.9, 135.6, 139.7, 140.1, 143.2, 153.2; Anal. Calcd. for $\mathrm{C}_{23} \mathrm{H}_{19} \mathrm{NO}_{2}(\%): \mathrm{C}, 80.92 ; \mathrm{H}, 5.61 ; \mathrm{N}, 4.10$. Found (\%): C, 80.85; H, 5.57; N, 4.04.

2.21 3-(4-Methoxyphenyl)-5,6-diphenyl-6H-1,2-oxazin6-ol (8e): Yellow colour solid; m.p. $179-181^{\circ} \mathrm{C}$; IR (KBr): 3209, 1632, 1498, 1213, 1012, $662 \mathrm{~cm}^{-1} ;{ }^{1} \mathrm{H}$ NMR $\left(300 \mathrm{MHz}, \mathrm{DMSO}-d_{6}\right): \delta=3.42(\mathrm{~s}, 3 \mathrm{H}), 7.13$ $(\mathrm{d}, J=7.5 \mathrm{~Hz}, 2 \mathrm{H}), 7.23-7.37(\mathrm{~m}, 4 \mathrm{H}), 7.52(\mathrm{~m}, 2 \mathrm{H})$, $7.68(\mathrm{~d}, J=7.5 \mathrm{~Hz}, 2 \mathrm{H}), 7.70(\mathrm{~d}, J=7.2 \mathrm{~Hz}, 2 \mathrm{H})$, $8.02(\mathrm{~s}, 1 \mathrm{H}), 8.30(\mathrm{~s}, 1 \mathrm{H}), 8.61(\mathrm{~d}, J=8.1 \mathrm{~Hz}, 2 \mathrm{H})$;<smiles>O=C(C(=O)c1ccccc1)c1ccccc1</smiles>
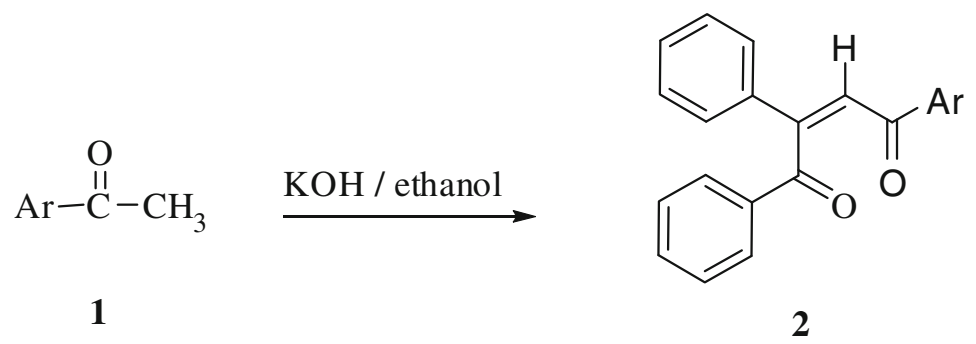
a) $\mathrm{Ar}=$ Phenyl; b) Ar = 4-Chlorophenyl;
c) $\mathrm{Ar}=4$-Bromophenyl; d) $\mathrm{Ar}=$ 4-Methylphenyl;
e) $\mathrm{Ar}=4$-Methoxyphenyl; f) $\mathrm{Ar}=5$-Bromo-2-thienyl

Scheme 1. Preparation of differently substituted phenyldibenzoylethylene. 


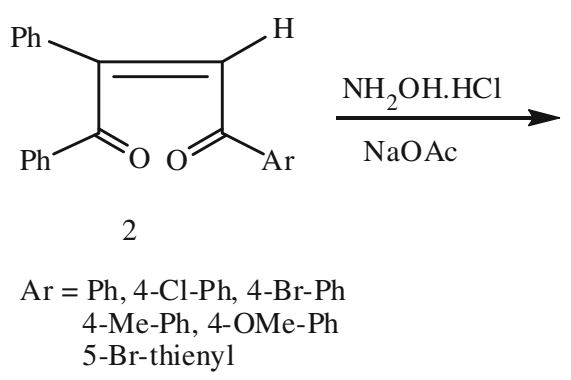<smiles>O=C(O)/C=C\C(=[V])c1ccccc1</smiles><smiles>[O-][N+]1=C([Al])C=C(c2ccccc2)C1(O)c1ccccc1</smiles><smiles>O=[N+]1C(c2ccccc2)=CC([Al])C1(O)c1ccccc1</smiles><smiles>OC1(c2ccccc2)C=CC(Br)=NO1</smiles>

Scheme 2. The reactions of hydroxylamine hydrochloride with differently substituted phenyldibenzoylethylene.

${ }^{13} \mathrm{C}$ NMR could not be recorded due to poor solubility; Anal. Calcd. for $\mathrm{C}_{23} \mathrm{H}_{19} \mathrm{NO}_{3}(\%)$ : C, 77.29; H, 5.36; N, 3.92. Found (\%): C, 77.08; H, 5.28; N, 3.88.

\section{Results and discussion}

The 1,2,4-Triaryl-but-2-ene-1,4-diones (2) can be prepared by the condensation of benzil and the derivatives of acetophenone/heteroaryl ketone ${ }^{13}$ (scheme 1 ). To the best of our knowledge, the ketone $2 \mathbf{f}$ is not reported in the literature.

1,2,4-Triaryl-but-2-ene-1,4-diones 2 were allowed to react with hydroxylamine hydrochloride and sodium acetate taken in 1:3:3 ratio. Excess hydroxylamine was used to ascertain complete hydroxylation in order to establish whether both the carbonyl groups are reactive towards the nucleophile or not. The course of the reaction was monitored by TLC. After $2 \mathrm{~h}$, the diketone vanished (TLC) and the products obtained were separated and analysed for their structures. The reaction has been conducted in different protic solvents and it was found that ethanol produced the best results.

Table 1. Isolated yields of the products 4, 7 and 8 .

\begin{tabular}{llccc}
\hline Entry & \multicolumn{1}{c}{ Aryl } & Yield of $\mathbf{4}$ & Yield of $\mathbf{7}$ & Yield of $\mathbf{8}$ \\
\hline a & Phenyl & - & 55 & 26 \\
b & 4-Chlorophenyl & - & 58 & 21 \\
c & 4-Bromophenyl & - & 48 & 23 \\
d & 4-Methylphenyl & - & 49 & 22 \\
e & 4-Methoxyphenyl & - & 61 & 20 \\
f & 5-Bromo-2-thienyl & 11 & 68 & - \\
\hline
\end{tabular}

The reaction has led to two products in all the case (scheme 2). While 2a to 2e have yielded 7 and $8,2 \mathbf{f}$ has led to $\mathbf{4 f}$ and $\mathbf{7 f}$ (table 1).

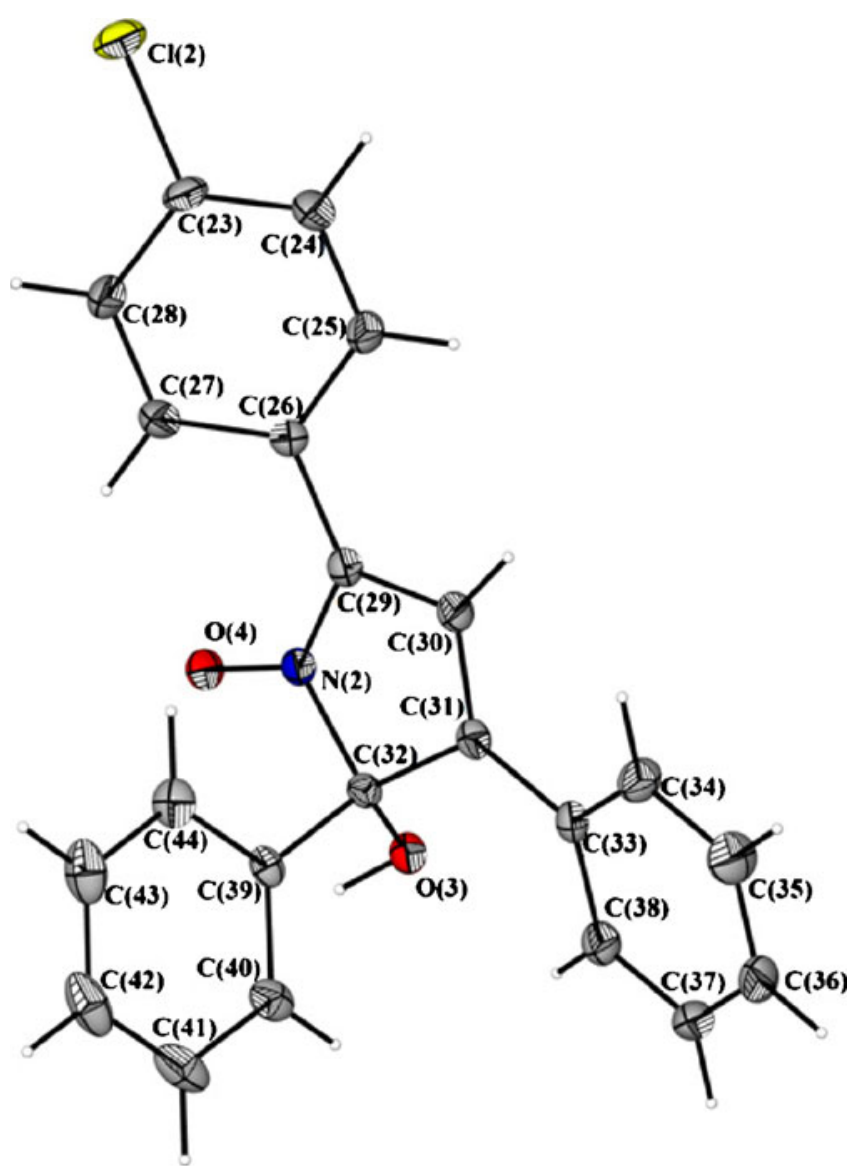

Figure 2. ORTEP diagram of $\mathbf{7 b}$. 

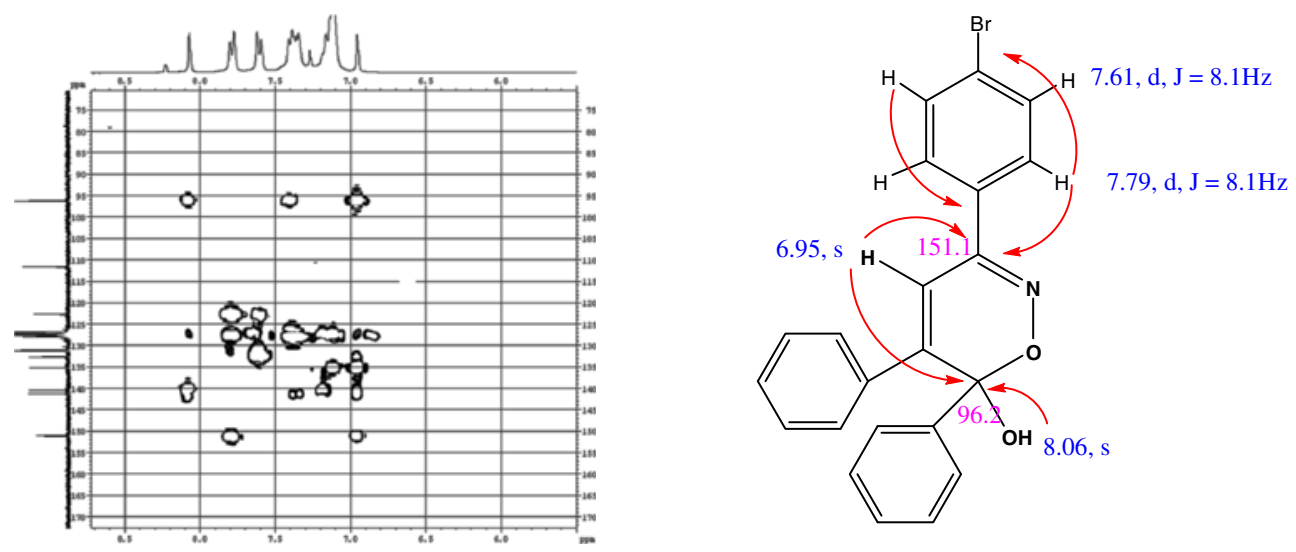

Figure 3. HMBC-NMR spectra of $\mathbf{8 C}$ and some selected correlation diagram.

The structure of nitrone 7 was established by ${ }^{1} \mathrm{H}$, ${ }^{13} \mathrm{C}$ and $2 \mathrm{D}$ NMR spectral data, ruling out the possibility of the regioisomer $\mathbf{6}$, as illustrated for a representative example 7e (figure 1). HMBC spectrum of 7e has contours connecting deshielded doublet at $8.61 \mathrm{ppm}$ with the carbons at $129.8 \mathrm{ppm}, 137.7 \mathrm{ppm}$ and $161.7 \mathrm{ppm}$. Thus, it is clear that these hydrogens are meta to methoxy group and this doublet is not giving any contour with the saturated quaternary carbon at $103.9 \mathrm{ppm}$.

But the doublet of doublet at $7.52 \mathrm{ppm}$ due to two hydrogen has HMBC connection with the carbon at $103.9 \mathrm{ppm}$. These informations helped to unambiguously assign the regiochemistry of the product 7 . Thus the $p$-anisyl group is attached to azomethine carbon, while the aryl is attached to the saturated quaternary carbon. The structure of the cyclic nitrone $\mathbf{7 b}$ was confirmed by single crystal X-ray analysis also (figure 2). ${ }^{14}$

Similarly the structure of 1,2-oxazine $\mathbf{8}$ has been established by ${ }^{1} \mathrm{H},{ }^{13} \mathrm{C}$ and $2 \mathrm{D}$ NMR spectral data as illustrated for a representative example 8c (figure 3). Here, it is noticed that the downfield two hydrogen signal at $7.79 \mathrm{ppm}$ is not a doublet of doublet, but a perfect doublet, which gives HMBC contour with the carbon at $151.1 \mathrm{ppm}$. Hence, the $p$-bromophenyl group is attached to the azomethine carbon. The olefinic singlet hydrogen at $6.95 \mathrm{ppm}$ has HMBC contour with the carbons at 96.2, 135.1, 140.5 and $151.1 \mathrm{ppm}$. The alcoholic proton appears at 8.06 singlet giving an HMBC contour with the carbon $96.2 \mathrm{ppm}$ revealing two bond connectivity, clearly establishing the structure of the molecule. The structure of $\mathbf{8 c}$ has been confirmed by single crystal X-ray analysis (figure 4). ${ }^{15}$

It can be noticed that in all the cases, the regioisomer 7, is formed exclusively and not $\mathbf{6}$. As hydroxylamine prefers to attack the less hindered carbonyl group, the intermediate $\mathbf{3}$ would have been formed from

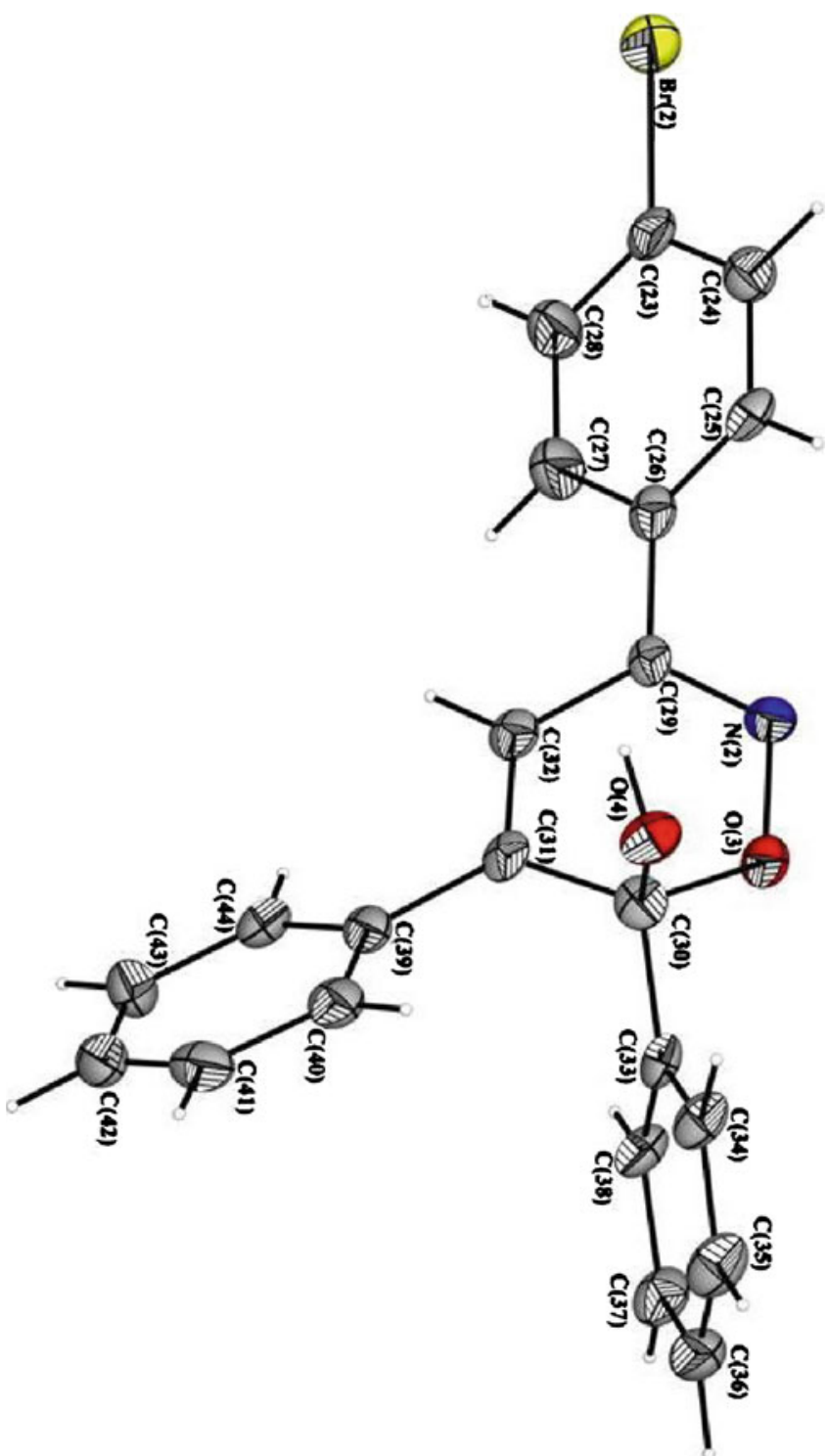

Figure 4. ORTEP diagram of $8 \mathbf{c}$. 


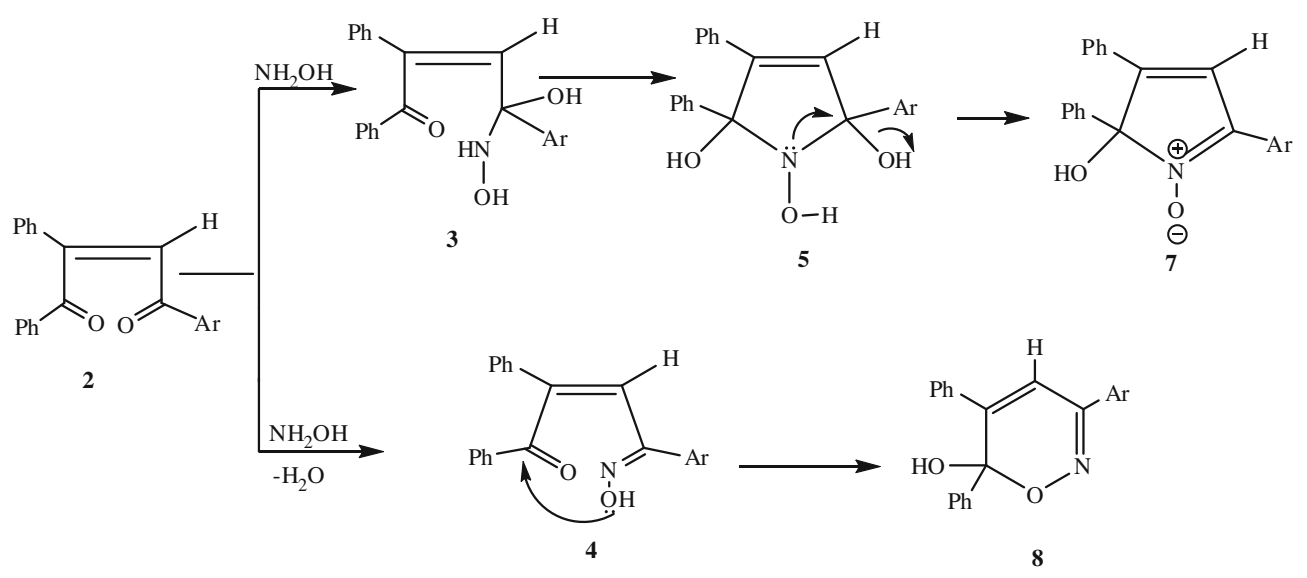

Scheme 3. Proposed mechanism.

2 (scheme 3) easily. This can undergo water elimination to give monooxime 4. But, the $-\mathrm{NHOH}$ group prefers to attack the other free carbonyl and forms the intermediate 5. Intermediate $\mathbf{5}$ can lose water molecule to form cyclic nitrone 7 . The oxygen of the oxime $\mathbf{4}$ can attack the free carbonyl carbon to form $\mathbf{8}$. But in $\mathbf{4 f}$, the oxime has not undergone the subsequent cyclisation. The above described steps are depicted in scheme 3 .

\section{Conclusion}

Reaction between differently substituted 1,4-diketones with hydroxylamine hydrochloride has been investigated. Cyclic nitrone, and 1,2-oxazine have been isolated and characterized adequately by NMR and single crystal X-ray analysis. Possible mechanism for the formation of these products has been suggested accounting for the observed regioselectivity.

\section{Supporting information}

The electronic supporting information can be seen in www.ias.ac.in/chemsci.

\section{Acknowledgements}

The authors thank the Department of Science and Technology (DST), New Delhi for assistance under the IRHPA program for providing funds for creating an NMR facility. MN thanks the Council of Scientific and Industrial Research (CSIR), New Delhi for JRF.

\section{References}

1. Breuer E, Aurich H G and Nielsen A 1989 Nitrones, nitronates and nitroxides (New Jersey: John Wiley and Sons); (b) Torsell K B G 1988 Nitrile oxides, nitrones and nitronates in organic synthesis (New York: VCH Publishers)

2. Sridharan V, Muthusubramanian S, Sivasubramanian S and Polborn K 2004 Tetrahedron 60 8881; (b) Jayapradha S R, Sridharan V, Muthusubramanian S and Polborn K 2007 J. Heterocycl. Chem. 44 1105; (c) Sridharan V, Saravanakumar S P and Muthusubramanian S 2005 J. Heterocycl. Chem. 42 515; (d) Dondas H A, Cummins J E, Grigg R and Thornton-Pett M 2001 Tetrahedron 57 7951; (e) Alibes R, Blanco P, de March P, Figueredo M, Font J, Alvarez-Larena A and Piniella J F 2003 Tetrahedron Lett. 44 523; (f) Gothelf K V and Jorgensen K A 2000 Chem. Commun. 1449; (g) Pineiro M and Pinhoe Melo T M V D 2009 Eur. J. Org. Chem. 5287; (h) Andrade M M, Barros M T and Pinto R C 2008 Tetrahedron 64 10521; (i) Blanarikova I, Dugovic D, Fisera L, Hametner C and Pronayova N 2001 Arkivoc 2109

3. Villamena F A and Zweier J L 2004 Antioxid. Redox Signaling. 6619

4. Floyd R A and Hensley K 2000 Ann. N. Y. Acad. Sci. 899 222; (b) Arya P, Stephens J C, Griller D, Pou S, Ramos C L, Pou W S and Rosen G M 1992 J. Org. Chem. 57 2297; (c) Fevig T L, Bowen S M, Janowick D A, Jones B K, Munson H R, Ohlweiler D F and Thomas C E 1996 J. Med. Chem. 39 4988; (d) Wang P- F, Gao P and Xu P-F 2006 Synlett 1095

5. McIntire G L, Blount H N and Janzen E G 1980 J. Phys. Chem. 84 916; (b) Reznikov V A, Gutorov I A and Rybalova T V 1996 Russ. Chem. Bull. 45 384; (c) O'Neil I A, Potter A J and Barkley J V 1998 Chem. Commun. 2511

6. Gough T E and Puzic R 1976 J. Magn. Reson. 23 31; (b) Zakrassov A, Shteiman V, Sheynin Y, Tumanskii B, Botoshansky M, Kapon M, Keren A, Kaftory M, Vos T E and Miller J S 2004 J. Mater. Chem. 141827

7. Reviews dealing with 1,2-oxazines in organic synthesis: (a) Gilchrist T L 1983 Chem. Soc. Rev. 12 53; (b) Lyapkalo I M and Ioffe S L 1998 Russ. Chem. Rev. 67 467; (c) Tsoungas P G 2002 Heterocycles 57 915; (d) Tsoungas P G 2002 Heterocycles 57 1149; (e) Santos J, Ignacio R, Aparicio D, Palacios F and Ezpeleta J M 2009 J. Org. Chem. 74 3444; (f) Winter C and Krause N 2009 Angew. Chem. 121 6457; (g) Tabolin A A, Lesiv A V, 
Khomutova Y A, Nelyubina Y V and Ioffe S L 2009 Tetrahedron 65 4578; (h) Lalonde, R L, Wang Z J, Mba M, Lackner A D and Toste F D 2010 Angew. Chem. 122 608

8. Terano H, Takase S, Hosoda J and Kohsaka M 1989 J. Antibiotics 42 145; (b) Lin Y, Shao Z, Jiang G, Zhou S, Cai J, Vrijmoed L P and Jones E B 2000 Tetrahedron 569607

9. Lee V J and Woodward R B 1979 J. Org. Chem. 44 2487

10. Uchida I, Takase S, Kayakiri H, Kiyoto S, Hashimoto M, Tada T, Koda S and Morimoto Y 1987 J. Am. Chem. Soc. 109 4108; (b) Iwami M, Kiyoto S, Terano $\mathrm{H}$, Kohsaka $\mathrm{M}$, Aoki $\mathrm{H}$ and Imanaka $\mathrm{H}$ 1987 J. Antibiotics 40 589; (c) Kiyoto S, Shibata T,
Yamashita M, Komori T, Okuhara M, Terano H, Kohsaka M, Aoki H and Imanaka H 1987 J. Antibiotics 40 594; (d) Shimomura K, Hirai O, Mizota T, Matsumoto S, Mori J, Shibayama F and Kikuchi H 1987 J. Antibiotics $\mathbf{4 0} 600$

11. Nagaraj M, Boominathan M, Muthusubramanian S and Bhuvanesh N 2011 Org. Biomol. Chem. 94642

12. Blatt A H 1934 J. Am. Chem. Soc. 56 2774; (b) Blatt A H 1936 J. Am. Chem. Soc. 58 590; (c) Blatt A H 1938 J. Org. Chem. 3 91; (d) Blatt A H 1950 J. Org. Chem. 15 869

13. Demirdji S H, Haddadin M J and Issidorides C H 1985 J. Heterocycl. Chem. 22495

14. CCDC No. 851421

15. CCDC No. 851422 